\title{
Calcium hydroxide fillings in curved canals: influence of apical enlargement using the rotary systems ProTaper, K3, and two hand instrumentation techniques
}

\author{
Preenchimento de canais curvos com hidróxido de cálcio: influência do \\ alargamento apical usando os sistemas rotatórios ProTaper, K3 e duas \\ técnicas de instrumentação manual
}

Jucimara Klein Alves Grazziotin

Lara Zanon Brum

Roberta Kochenborger Scarparo*

Renata Dornelles Morgental ${ }^{* * *}$

Marcus Vinícius Reis Só ${ }^{* * * *}$

Fabiana Vieira Vier-Pelisser ${ }^{* *}$

\section{Abstract}

Objective: This study aimed to analyze the influence of the instrumentation technique (hand or rotary), and apical enlargement on calcium hydroxide $(\mathrm{CH})$ fillings in curved canals. Materials and method: One hundred and ten simulated root canals were divided into eleven experimental groups $(G)$. Canals were prepared with K-Flexofile hand instruments, using either crown-down (GCD 25, GCD 30 and GCD 35) or step-back (GSB 25, GSB 30 and GSB 35) techniques; and with rotary instruments, using either ProTaper (GPT F1 and GPT F2) or K3 (GK3 25, GK3 30 and GK3 35) systems. The apical diameter corresponded to $0.20 \mathrm{~mm}$ (GPT F1), $0.25 \mathrm{~mm}$ (GCD 25, GSB 25, GPT F2 and GK3 25), $0.30 \mathrm{~mm}$ (GCD 30, GSB 30, GK3 30), and $0.35 \mathrm{~mm}$ (GCD 35, GSB 35, GK3 35). A CH paste, previously colored with blue Indian ink, was injected into the canals using a special syringe. The four sides of the blocks with simulated canals were scanned and the images were transferred to the AutoCAD-2008 software, for assessing the amount (\%) of filling in the apical $5 \mathrm{~mm}$
(ANOVA; Tukey's Test; $\alpha=0.05$ ). Qualitative analysis was also performed regarding the presence or absence of voids (Chi-square Test; $\alpha=0.05$ ). Results: In GSB, there was significant difference between diameters 25 and 30 . GSB showed lower amount of filling $(P<0.05)$ than GK3, when the apical diameter corresponded to $0.30 \mathrm{~mm}$. GCD showed lower amount of filling $(P<0.05)$ than the other groups (SB, PT, and K3), when the apical diameter corresponded to $0.25 \mathrm{~mm}$. No significant difference was detected when comparing the four sides of the blocks. Conclusion: Preparation technique and apical diameter had slight or no relevant influence on $\mathrm{CH}$ paste filling in simulated curved root canals. Statistical differences found in this study may be clinically irrelevant, since the amount of filling, regardless of preparation technique and apical diameter, was very close or equal to $100 \%$.

Keywords: Endodontics. Root canal preparation. Calcium hydroxide.

PhD, Professor, Department of Endodontics, School of Dentistry, Pontifical Catholic University of Rio Grande do Sul (PUCRS), Porto Alegre, RS, Brazil.

$* *$ PhD, Post-Doctoral Student, Department of Endodontics, School of Dentistry, Pontifical Catholic University of Rio Grande do Sul (PUCRS), Porto Alegre, RS, Brazil.

${ }^{* * *}$ PhD, Professor, Department of Endodontics, School of Dentistry, Federal University of Rio Grande do Sul (PUCRS), Porto Alegre, RS, Brazil. 


\section{Introduction}

Endodontic literature has clearly established the correlation among the presence of bacteria, their byproducts and apical periodontitis ${ }^{1,2}$. Therefore, the main goal of endodontic treatment is to prevent or eliminate infection within root canal systems. Numerous investigations have shown the limited efficiency of mechanical preparation in cleaning the apical third of root canals ${ }^{3,4}$. Thus, additional chemical disinfection promoted by irrigating solutions and root canal dressings has been suggested ${ }^{3,5-7}$.

Calcium hydroxide $(\mathrm{CH})$ is one of the most commonly used substances in endodontics. Its antibacterial property stems from its ability to dissociate into calcium and hydroxyl ions resulting in increased $\mathrm{pH}$. The beneficial effect of $\mathrm{CH}$ has been related to the break up of fatty acids from gram-negative bacteria, inactivation of endotoxins, and damage to bacterial $\mathrm{DNA}^{8-10}$. On the other hand, the effectiveness of $\mathrm{CH}$-based pastes depends on their direct contact with the canal walls ${ }^{11-15}$, which may be limited by anatomical difficulties in curved canals ${ }^{12}$.

The improvement of instrumentation techniques and the advent of nickel-titanium (NiTi) rotary instruments enabled increased apical enlargements, and more centered and tapered preparations in curved canals ${ }^{15,16}$. Previous studies have shown that the canal preparation size, as the instrumentation technique, significantly influences the mechanical efficacy of irrigation ${ }^{17,18}$. On the other hand, their ability to improve root canal obturation is controversial $^{19}$, and their effect on the quality of $\mathrm{CH}$ fillings in curved canals should be further investigated.

Over the years, the understanding of root canal anatomical features has been considered to improve instrumentation techniques. In this regard, aspects such as the normal dentin apposition in the cervical region and root canals tapered shape ${ }^{20}$ has been taken into account when determining changes on instrument sequences and designs. Hereof, step-back and crown-down techniques using taper .02 hand files have been suggested to replace the classical instrumentation technique ${ }^{21}$. Moreover, considering NiTi alloy properties, several rotary systems were suggested. The first introduced rotary systems, in which K3 (Sybron Endo, Orange County, CA, USA) is included, offers sequences of instruments with different tapers, ranging from .02 to .12, although keeping ISO-sized tips (ISO 3630-1), as well as a single value of taper for each file ${ }^{22}$. The option of greater taper allows coronal enlargement during canal instrumentation, enabling safer apical preparations. Instruments presenting variable tapers in the same shaft, such as ProTaper (Dentsply Maillefer, Ballaigues, Switzerland), were designed later, aiming to reduce the number of instruments, while improving the coronal dilatation and avoiding the contact of the file tip with dentinal walls.

The aim of this study was to assess the effect of instrumentation techniques (hand or rotary instruments) and apical enlargement on $\mathrm{CH}$ fillings in simulated curved canals.

\section{Materials and method}

The sample comprised 110 acrylic blocks with simulated root canals with $35^{\circ}$ apical curvature (Endo Training Blocks; Dentsply-Maillefer, Ballaigues, Switzerland) which were randomly assigned to 11 experimental groups $(\mathrm{n}=10)$, according to the instrumentation technique and apical enlargement (Table 1). Canal instrumentation was performed with K-Flexofile hand instruments (Dentsply-Maillefer, Ballaigues, Switzerland) using either crown-down (CD) or step-back (SB) technique, and rotary instrumentation using either ProTaper Universal (PT) (Dentsply-Maillefer, Ballaigues, Switzerland) or K3 (SybronEndo, Orange, CA, USA) systems. For hand techniques, the canals were prepared up to sizes 25, 30, and 35 instruments; for ProTaper, apical stops were established by using F1 (20/.07) and F2 (25/.08) instruments; for K3, apical stops were prepared using 25/.06, 30/.04, and 35/.06 instruments.

Table 1 - Experimental groups, according to preparation technique and apical enlargement

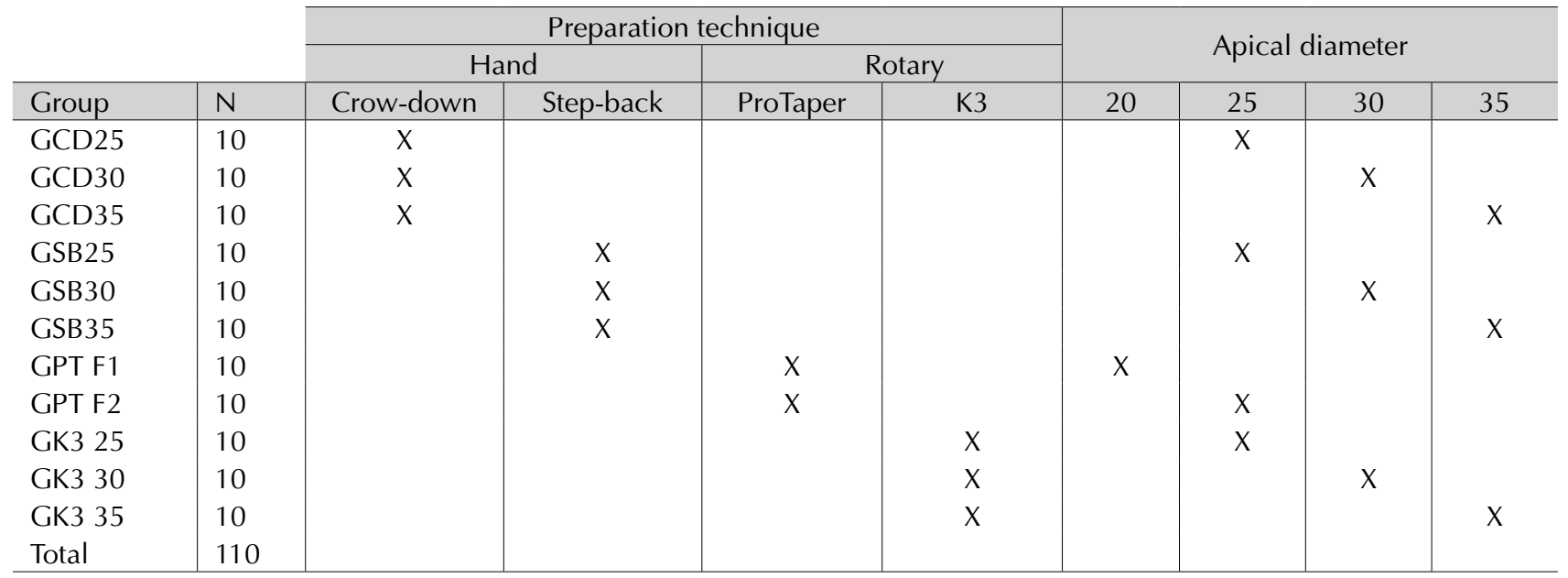


All simulated canals were irrigated with $1 \%$ sodium hypochlorite $(\mathrm{NaOCl})$ (Biodinâmica Química e Farmacêutica, Ibiporã, PR, Brazil) and initially explored with size $15 \mathrm{~K}$-Flexofile instruments at the working length (WL; $16 \mathrm{~mm}$ ). A single operator blinded to the groups performed root canal preparations and $\mathrm{CH}$ fillings. Throughout the experiment, acrylic blocks were maintained in a fixed position with a holding device (Neboluz Comercial de Ferramentas Ltda, São Paulo, SP, Brazil).

\section{Hand Preparation}

\section{Crown-down technique}

Instrumentation was initiated with a large-sized instrument, with a brushstroke action against canal walls and no pressure towards the apex. Two sequential instruments of smaller sizes were used intercalating with $\mathrm{NaOCl}$ irrigation, and a size 10 K-file was introduced up to the WL. Coronal preflaring was carried out with \#1 and \#2 Gates-Glidden drills, and hand instruments of decreasing size were used until the WL was reached. The apical stop was prepared using anticurvature brushing movements with sizes 25,30 or $35 \mathrm{~K}$-Flexofile instruments, according to the group. Soon after, canals were prepared by stepping back $1 \mathrm{~mm}$ a time with three subsequently larger instruments. During the crown-down approach, canals were explored with a size $10 \mathrm{~K}$-file at the WL. Likewise, during the step-back stage, the master apical file was used at each change of file at the WL.

\section{Step-back technique}

The preparation was initiated with a size $15 \mathrm{~K}$ -Flexofile. Larger-sized instruments were sequentially used along the entire WL, using anticurvature movements, until reaching an apical diameter of 25,30 or 35 , according to the group. Afterwards, simulated canals were additionally prepared with three larger instruments, decreasing the WL in 1 $\mathrm{mm}$ for each change of file.

\section{Rotary Preparation}

Rotary instrumentation was performed using an electric engine (X Smart, Dentsply-Maillefer, Ballaigues, Switzerland) activated at $300 \mathrm{rpm}$ and $2 \mathrm{~N} / \mathrm{cm}$ torque. Continuous and pressureless movements were established. For ProTaper, preparation started with $\mathrm{S} 1$ and SX instruments at the coronal third followed by S2 instruments at the middle third, with brushing action in a crown-down mode. Apical stop was prepared either with F1 or F2 instruments. For K3, Variable Tip Variable Taper (VTVT) technique was employed, according to manufacturer's instructions. Sequentially, \#25/.10, \#25/.08, 35/.06, 30/.04, and 25/.06 instruments were employed. To prepare the apical stop, instruments were used in reverse order, establishing the following final apical diameters: $25 / .06,30 / .04$ or $35 / .06$.

Hand and rotary instruments were discarded after every 5 preparations. Following instrumentation, canals were dried with absorbent paper points.

\section{Intracanal delivery of $\mathrm{CH}$ paste}

A commercial $\mathrm{CH}$ paste supplied in a cartridge was used in this study (Calen ${ }^{\mathrm{TM}}$; S.S. White Artigos Dentários Ltda, Rio de Janeiro, RJ, Brazil). Its composition includes: $2.5 \mathrm{~g} \mathrm{CH}, 0.5 \mathrm{~g}$ zinc oxide, 0.05 $\mathrm{g}$ colophony, and $1.75 \mathrm{~mL}$ polyethylene glycol 400 (vehicle). The paste was delivered from its cartridge on a glass plate, thoroughly mixed with 2 drops of blue Indian ink (Acrilex, São Paulo, SP, Brazil), and the mixture was repacked into the cartridge. The blue-stained $\mathrm{CH}$ paste was injected into the canals using a special endodontic syringe (ML syringe ${ }^{\mathrm{TM}}$; S.S. White Artigos Dentários Ltda, Rio de Janeiro, RJ, Brazil) and a long 27G needle (Septoject XL; Septodont, Saint-Maur-des-Fossés, Cedex, France) with a silicone stopper set at the WL. The coronal portion was sealed with $2 \mathrm{~mm}$ of temporary restorative material (Coltosol $^{\mathrm{TM}}$; Coltene-Whaledent, Cuyahoga Falls, OH, USA).

\section{Image Acquisition}

The four sides of the transparent blocks were scanned at a 600 dpi resolution with a flatbed scanner (Genius ColorPage-HR6X; Kye Systems Corp, Houjie, China). Having the operator as a reference point, the root curvature was disposed to the operator's left, which was considered as the mesial surface in this study. The block was turned in a clockwise direction on the scanner bed, in such a way that the root curvature was then disposed to the front, right, and backsides, simulating the buccal, distal and palatal surfaces, respectively. Thus, four images were obtained, one from each aspect: left or mesial (M), front or buccal (B), right or distal (D), and back or palatal $(\mathrm{P})$. These images were exported to the AutoCAD-2008 software (Autodesk Inc; McInnis Parkway, San Rafael, CA, USA) for quantitative and qualitative analyses.

\section{Quantitative Measurement}

First, the apical $5 \mathrm{~mm}$ were standardized with a special tool of the AutoCAD software (Polyline), in comparison to the WL $(16 \mathrm{~mm})$. Second, the total area in the apical $5 \mathrm{~mm}$ was determined. Then, areas of voids, i.e., regions not filled with the blue-stained $\mathrm{CH}$ paste, were measured (Fig. 1). 

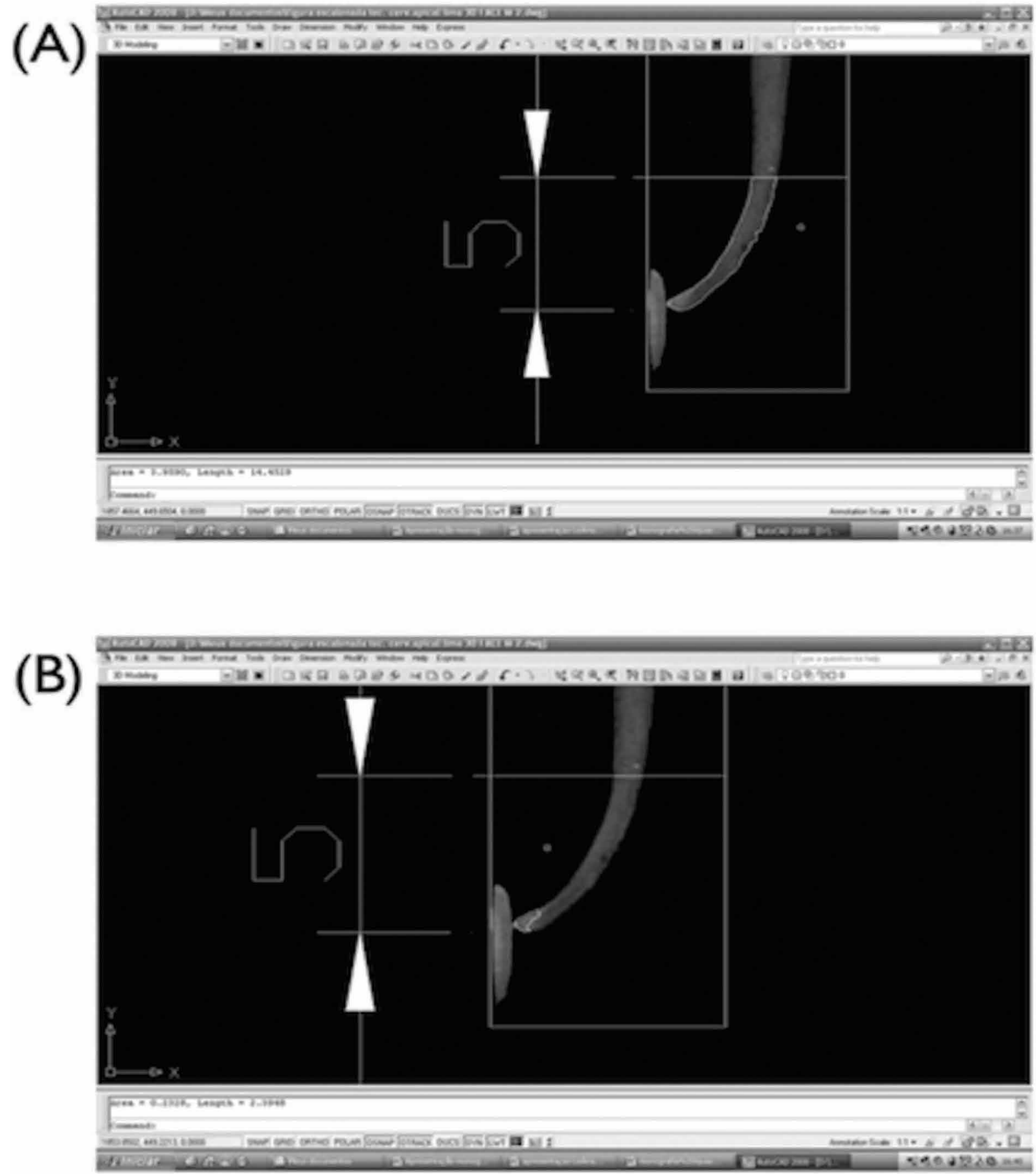

Figure 1 - Method adopted for calcium hydroxide (CH) filling assessment: (A) area delimitation in the apical $5 \mathrm{~mm}$; (B) determination of areas without $\mathrm{CH}$ paste. Based on these measures, the amount of $\mathrm{CH}$ filling was calculated

The amount of $\mathrm{CH}$ paste and the amount of filling deficiencies in the apical $5 \mathrm{~mm}$ were considered for statistical purposes. Data were analyzed by ANOVA and Tukey's post-hoc test at 5\% significance level.

\section{Qualitative Measurement}

The presence or absence of voids in the apical third of the simulated canals was recorded for each surface (B, M, D, and P). In this qualitative analy- sis, preparation technique and apical diameter were not considered; it was conducted for detecting possible differences between surfaces. Data were analyzed by chi-square test complemented by adjusted residues analysis. A significance level of 5\% was established. 


\section{Results}

Since ProTaper presents different patterns of apical diameters, when analyzing the influence of apical enlargement on paste voids, only hand techniques and the K3 system were considered (Table 2 ). In this assessment, the comparison of apical diameters in each technique showed significant di- fferences only related to the step-back preparation, between sizes 25 and $30(p<0.05)$. Although all groups showed amount of filling close to $100 \%$, in the comparison of preparation techniques in each apical diameter, significant differences could be observed between the step-back technique and the K3 system $(p<0.05)$ when evaluating size 30 apical preparation. The rotary system showed higher amount of filling than the hand technique.

Table 2 - Mean percentage of calcium hydroxide filling in simulated curved canals prepared with different techniques and apical diameters

\begin{tabular}{|c|c|c|c|c|c|c|}
\hline \multirow{3}{*}{ Technique* } & \multicolumn{6}{|c|}{ Diameter } \\
\hline & \multicolumn{2}{|c|}{25} & \multicolumn{2}{|c|}{30} & \multicolumn{2}{|c|}{35} \\
\hline & Mean & $\mathrm{SD}( \pm)$ & Mean & $\operatorname{SD}( \pm)$ & Mean & $\mathrm{SD}( \pm)$ \\
\hline GCD & $99.78^{\mathrm{Aa}}$ & 0.28 & $99.84^{\mathrm{ABa}}$ & 0.43 & $99.93^{\mathrm{Aa}}$ & 0.17 \\
\hline GSB & $99.99^{\mathrm{Aa}}$ & 0.05 & $99.59^{\mathrm{Bb}}$ & 1.00 & $99.85^{\text {Aab }}$ & 0.32 \\
\hline GK3 & $100.00^{\mathrm{Aa}}$ & 0.00 & $99.90^{\text {Аа }}$ & 0.16 & $99.98^{\mathrm{Aa}}$ & 0.09 \\
\hline
\end{tabular}

* In this analysis, ProTaper group was not considered.

SD: standard-deviation.

Distinct capital letters in the columns and distinct small letters in the rows indicate statistically significant difference $(\alpha=0.05)$.

To assess the effects of instrumentation techniques, only instruments with an apical diameter of $0.25 \mathrm{~mm}$ were considered in the analysis, including ProTaper F2 instruments, since all techniques contemplate a group with this limit of apical enlarge- ment. Table 3 shows that, regardless of block side, the crown-down technique presented significantly lower mean percentage of calcium hydroxide fillings than the other techniques. However, all techniques showed an amount of filling very close or equal to $100 \%$.

Table 3 - Mean percentage of calcium hydroxide filling in simulated curved canals prepared with different techniques, with size 25 apical diameters

\begin{tabular}{l|c|r}
\multicolumn{1}{c|}{ Group } & Mean & Standard-deviation ( \pm ) \\
\hline GCD & $99.78^{\mathrm{B}}$ & 0.28 \\
GSB & $99.99^{\mathrm{A}}$ & 0.05 \\
GPT & $99.98^{\mathrm{A}}$ & 0.08 \\
GK3 & $100.00^{\mathrm{A}}$ & 0.00 \\
\hline
\end{tabular}

Distinct letters indicate significant difference according to ANOVA and Tukey's test $(\alpha=0.05)$.

Qualitative analysis is shown in Table 4. Chi-square test $(p=0.074)$ indicated that there was no association between filling voids and block sides.

Table 4 - Presence and absence of filling deficiencies in different block sides

\begin{tabular}{|c|c|c|c|c|c|c|}
\hline \multirow{3}{*}{ Side } & \multicolumn{4}{|c|}{ Apical filling } & \multirow{2}{*}{\multicolumn{2}{|c|}{ Total }} \\
\hline & \multicolumn{2}{|c|}{ Without voids } & \multicolumn{2}{|c|}{ With voids } & & \\
\hline & $N$ & $\%$ & $N$ & $\%$ & $\mathrm{n}$ & $\%$ \\
\hline M & 88 & 80.0 & 22 & 20.0 & 110 & 100.0 \\
\hline $\mathrm{D}$ & 75 & 68.2 & 35 & 31.8 & 110 & 100.0 \\
\hline$P$ & 86 & 78.2 & 24 & 21.8 & 110 & 100.0 \\
\hline B & 90 & 81.8 & 20 & 18.2 & 110 & 100.0 \\
\hline Total & 339 & 77.0 & 101 & 23.0 & 440 & 100,0 \\
\hline
\end{tabular}

$\chi^{2}=6.927 ; p=0.074$ 


\section{Discussion}

The present study showed that appropriate $\mathrm{CH}$ fillings could be achieved in simulated curved canals after using either hand or rotary preparation techniques. The quality of $\mathrm{CH}$ fillings has been extensively investigated but most studies are limited to comparisons of different techniques for $\mathrm{CH}$ placement within root canals ${ }^{12-14,23-28}$. Also, some previous results have pointed out that severe root canal curvature ${ }^{13}$ and small apical diameters ${ }^{28}$ may impair the optimal delivery of $\mathrm{CH}$ pastes. However, this was not confirmed in the study performed by Vier-Pelisser et al. ${ }^{29}$ (2012). The authors tested hand and ProTaper rotary instruments, using crown-down approaches, and no difference between preparation techniques or between apical diameters (size 25 to 35 ) was detected. In the present investigation, the K3 rotary system was additionally tested, but similar results were found.

NiTi rotary instruments have significantly changed the way root canal preparation is performed, making it extremely important to evaluate the influence of instrumentation techniques on the quality of $\mathrm{CH}$ fillings in curved canals. It is noteworthy that, in this study, a single technique to introduce the $\mathrm{CH}$ paste into the canal was chosen, thus variables were limited to preparation technique and extent of apical enlargement. $\mathrm{CH}$ dressing placement was carried out by using an injection system (ML syringe ${ }^{\mathrm{TM}}$ ), which has proven to be effective previously ${ }^{29,30}$.

The use of simulated root canals was based on the possibility of sample standardization regarding curvature length and degree ${ }^{24-26}$. Also, the current study assessed the apical third of curved canals, as previous studies have shown this is the most difficult region to be completely filled by $\mathrm{CH}$ dressings $\mathrm{s}^{23,29}$.

Different assessment methods have been used for analyzing $\mathrm{CH}$ placement, such as weighing ${ }^{28}$ and radiographic examination ${ }^{12,24-26}$. In the present stu$\mathrm{dy}$, the four sides of the acrylic blocks were scanned to provide a more accurate analysis. To date, apart from tooth clearing ${ }^{27}$, which also allows a three-dimensional analysis of the intracanal dressing filling, only two-dimensional radiographs ${ }^{12,24-26}$ have been used. Another relevant methodological aspect of this experiment was the quantitative analysis, assessing the mean percentage of canal filling, and not only a qualitative analysis based on scores, as reported by several authors ${ }^{12,24,27}$.

Concerning the effect of preparation techniques on paste fillings, significant difference was observed when comparing the step-back technique and the K3 system, showing that tapered preparations may avoid gaps in intracanal dressings. However, this finding was restricted to size 30 apical diameters. Furthermore, despite this statistical difference, the amount of filling was very close to $100 \%$ in all groups.
Furthermore, in GSB, size 30 had significantly lower percentage of filling than size 25. Actually, in GSB, the higher the apical diameter, the greater the occurrence of apical deviation, resulting in elbows or zips, since coronal preflaring was not conducted in this group. These procedural errors may have impaired the proper filling of the apical portion. Again, despite the mathematical difference, the percentage of filling was very close or equal to $100 \%$ in all groups. Thus, this discrepancy may not be clinically relevant. According to these findings, further enlargement did not determine a decrease in paste voids.

Although there is disagreement amongst endodontic specialists about the ideal apical diameter of root canal preparation, there is universal consensus that the ideal size depends on anatomical, microbiological, and mechanical factors ${ }^{31,32}$. The majority of studies demonstrate that larger apical preparation sizes result in a greater reduction in the remaining bacteria and debris compared to smaller apical diameters ${ }^{17,33}$. On the other hand, over-enlargement may cause weakening of dental structure ${ }^{31}$ and, especially when hand techniques are used, may lead to apical deviation ${ }^{34}$. Considering the additional effects of irrigation and intracanal medications, the need for greater enlargement seems unnecessary. The possibility of filling the apical third of curved canals with calcium hydroxide dressings, as demonstrated herein, should contribute to canals disinfection when anatomical features are interposed.

Often, during chemomechanical preparation in severely curved canals, apical stop is established with small diameter instruments, due to the technical difficulty of enlargement. In the present study, it was possible to compare the four preparation techniques exclusively in those groups prepared up to size 25 . The explanation relies on the fact that in canals prepared with ProTaper, the use of F3 instruments corresponding to $0.30 \mathrm{~mm}$ would probably culminate in fracture and the consequent loss of the sample.

Another important aspect to be mentioned is the frequent presence of apical deviation in the groups of hand instrumentation, especially those with apical stops corresponding to $0.35 \mathrm{~mm}$. Thus, in severely curved canals, endodontists are faced with a dilemma: to either enlarge the apical region more at the risk of instrument fracture $\mathrm{s}^{35}$ and deviations ${ }^{34}$ or prepare it less and maybe not completely disinfect the root canal system. Simchock and Hicks ${ }^{28}$ (2006) found that worse results regarding voids within $\mathrm{CH}$ dressing fillings were obtained in small apical diameters (size 25) when compared to canals prepared up to size 40 . However, according to our results, the amount of $\mathrm{CH}$ filling approached $100 \%$ for all techniques, even in canals prepared to size 25 , and a larger instrumentation would be dispensable for this matter. On the other hand, the technique used for inserting the $\mathrm{CH}$ paste is probably a determinant 
factor to achieve an adequate filling, and the ML endodontic syringe proved to be effective.

According to quantitative and qualitative assessments, the area closest to the apical stop is where voids were most commonly observed within the medication. Only very small voids were verified (Figure 1B). On the other hand, Sigurdsson et al. ${ }^{12}$ (1992) reported that the filling quality was less than adequate in relation to apical limit and density. Estrela et al. ${ }^{23}$ (2001) verified that the apical canal third hardly ever proved to be fully completed by the $\mathrm{CH}$ paste in their sample. A greater number of failures in the apical region could be explained by the difficulty of inserting the medication in this portion, since this is the farthest location from the canal entrance. In the present study, caution was taken to introduce the injection system needle the closest possible to the WL to ensure an adequate filling.

Based on our findings, $\mathrm{CH}$ filling was not affected by block side. In contrast, Vier-Pelisser et al. ${ }^{29}$ (2012) identified better filling when the curvatures of the canals were directed to mesial and distal. For the authors, curved canals for vestibular and palatal could be present as clinically flawed, with voids within medication, and this problem could go radiographically undetected.

Lastly, studies related to possible factors that might influence successful canal filling with $\mathrm{CH}$ dressing paste should be fully exhausted.

\section{Conclusion}

The results obtained in the present study led to the conclusion that appropriate calcium hydroxide fillings can be achieved in simulated curved canals after using either hand or rotary preparation techniques, with a minimum apical diameter of 0.25 $\mathrm{mm}$. Statistical differences found in this study may be clinically irrelevant, once the amount of filling, regardless of preparation technique and apical diameter, was very close or equal to $100 \%$.

\section{Resumo}

Objetivo: Este estudo teve como objetivo analisar a influência da técnica de instrumentação (manual ou rotatória) e do alargamento apical no preenchimento de canais curvos com hidróxido de cálcio (HC). Materiais e método: Cento e dez canais simulados foram divididos em onze grupos experimentais $(G)$. Os canais foram preparados com instrumentos manuais K-Flexofile, usando a técnica cérvico-apical (GCA 25, GCA 30 e GCA 35) ou ápico-cervical (GAC 25, GAC 30 e GAC 35), e com instrumentos rotatórios do sistema ProTaper (GPT F1 e GPT F2) ou sistema K3 (GK3 25, GK3 30 e GK3 35). O diâmetro apical correspondia a 0,20 mm (GPT F1), 0,25 mm (25 GCA, GAC 25, GPT F2 e GK3 25), 0,30 mm (GCA 30, GAC 30, GK3 30) e 0,35 mm (GCA 35, GAC 35, GK3 35). Uma pasta de HC, previamente pigmen- tada com nanquim, foi injetada nos canais utilizando uma seringa especial. Os quatro lados dos blocos com canais simulados foram digitalizados e as imagens foram transferidas para o software AutoCAD-2008, para avaliar a porcentagem (\%) de preenchimento nos $5 \mathrm{~mm}$ apicais (ANOVA; Teste de Tukey; $\alpha=0,05$ ). Uma análise qualitativa também foi realizada, em relação à presença ou ausência de espaços vazios (Teste Qui-quadrado; $\alpha=0,05)$. Resultados: Em GAC, houve diferença significativa entre os diâmetros 25 e 30. GAC apresentou menor porcentagem de preenchimento $(P<0,05)$ do que GK3, quando o diâmetro apical correspondia a 0,30 $\mathrm{mm}$. GCA apresentou menor preenchimento $(P<0,05)$ do que os outros grupos (AC, PT e K3), quando o diâmetro apical correspondia a $0,25 \mathrm{~mm}$. Não foi observada diferença significativa na comparação entre os quatro lados dos blocos. Conclusão: A técnica de preparo e o diâmetro apical apresentaram pouca ou nenhuma influência relevante no preenchimento de canais radiculares curvos simulados com pasta de HC. As diferenças estatísticas encontradas neste estudo podem ser clinicamente irrelevantes, uma vez que a quantidade de preenchimento, independentemente da técnica de preparo e diâmetro apical, foi muito próximo ou igual a $100 \%$.

Palavras-chave: Endodontia. Preparo de canal radicular. Hidróxido de cálcio.

\section{References}

1. Kakehashi S, Stanley HR, Fitzgerald RJ. The Effects of surgical exposures of dental pulps in germ-free and conventional laboratory rats. Oral Surg Oral Med Oral Pathol 1965; 20:340-9.

2. Moller AJ, Fabricius L, Dahlen G, Ohman AE, Heyden G. Influence on periapical tissues of indigenous oral bacteria and necrotic pulp tissue in monkeys. Scand J Dent Res 1981; 89(6):475-84.

3. Card SJ, Sigurdsson A, Orstavik D, Trope M. The effectiveness of increased apical enlargement in reducing intracanal bacteria. J Endod 2002; 28(11):779-83.

4. Fornari VJ, Silva-Sousa YT, Vanni JR, Pecora JD, Versiani MA, Sousa-Neto MD. Histological evaluation of the effectiveness of increased apical enlargement for cleaning the apical third of curved canals. Int Endod J 2010; 43(11):988-94.

5. Soares JA, Leonardo MR, da Silva LA, Tanomaru Filho M, Ito IY. Elimination of intracanal infection in dogs' teeth with induced periapical lesions after rotary instrumentation: influence of different calcium hydroxide pastes. J Appl Oral Sci $2006 ; 14(3): 172-7$.

6. Siqueira JF Jr, Magalhaes KM, Rocas IN. Bacterial reduction in infected root canals treated with $2.5 \% \mathrm{NaOCl}$ as an irrigant and calcium hydroxide/camphorated paramonochlorophenol paste as an intracanal dressing. J Endod 2007; 33(6):667-72

7. Siqueira JF Jr, Paiva SS, Rocas IN. Reduction in the cultivable bacterial populations in infected root canals by a chlorhexidine-based antimicrobial protocol. J Endod 2007; 33(5):541-7.

8. Tronstad L, Andreasen JO, Hasselgren G, Kristerson L, Riis I. $\mathrm{pH}$ changes in dental tissues after root canal filling with calcium hydroxide. J Endod 1981; 7(1):17-21. 
9. Siqueira JF Jr, Lopes HP. Mechanisms of antimicrobial activity of calcium hydroxide: a critical review. Int Endod J 1999; 32(5):361-9.

10. Tanomaru JM, Leonardo MR, Tanomaru Filho M, Bonetti Filho I, Silva LA. Effect of different irrigation solutions and calcium hydroxide on bacterial LPS. Int Endod J 2003; 36(11):733-9.

11. Dumsha TC, Gutmann JL. Clinical techniques for the placement of calcium hydroxide. Compend Contin Educ Dent 1985; 6(7):482-3,486,488-9.

12. Sigurdsson A, Stancill R, Madison S. Intracanal placement of $\mathrm{Ca}(\mathrm{OH})_{2}$ : a comparison of techniques. J Endod 1992; 18(8):367-70.

13. Fava LR, Otani AY. Available techniques for calcium hydroxide placement within the root canal. Braz Endod J 1998; 3:34-42.

14. Deveaux E, Dufour D, Boniface B. Five methods of calcium hydroxide intracanal placement: an in vitro evaluation. Oral Surg Oral Med Oral Pathol Oral Radiol Endod 2000; 89(3):349-55.

15. Pasternak-Junior B, Sousa-Neto MD, Silva RG. Canal transportation and centring ability of RaCe rotary instruments. Int Endod 2009; 42(6):499-506.

16. Versiani MA, Pascon EA, de Sousa CJ, Borges MA, Sousa-Neto MD. Influence of shaft design on the shaping ability of 3 nickel-titanium rotary systems by means of spiral computerized tomography. Oral Surg Oral Med Oral Pathol Oral Radiol Endod 2008; 105(6):807-13.

17. Falk KW, Sedgley CM. The influence of preparation size on the mechanical efficacy of root canal irrigation in vitro. J En$\operatorname{dod} 2005 ; 31(10): 742-5$.

18. Boutsioukis C, Gogos C, Verhaagen B, Versluis M, Kastrinakis E, Van der Sluis LW. The effect of root canal taper on the irrigant flow: evaluation using an unsteady Computational fluid dynamics model. Int Endod J 2010; 43(10):909-16.

19. van der Borden WG, Wu MK, Wesselink PR. Percentages of gutta-percha-filled canal area observed after increased apical enlargement. J Endod 2010; 36(1):139-42.

20. Leeb J. Canal orifice enlargement as related to biomechanical preparation. J Endod 1983; 9(11):463-70.

21. Wu MK, Wesselink PR. Efficacy of three techniques in cleaning the apical portion of curved root canals. Oral Surg Oral Med Oral Pathol Oral Radiol Endod 1995; 79(4):492-6.

22. McSpadden JT. Mastering endodontic instrumentation. New York: Arbor Books; 2007.

23. Estrela C, Bammann LL, Pimenta FC, Pecora JD. Control of microorganisms in vitro by calcium hydroxide pastes. Int Endod J 2001; 34(5):341-5.

24. Oztan MD, Akman A, Dalat D. Intracanal placement of calcium hydroxide: a comparison of two different mixtures and carriers. Oral Surg Oral Med Oral Pathol Oral Radiol Endod 2002; 94(1):93-7.

25. Torres CP, Apicella MJ, Yancich PP, Parker MH. Intracanal placement of calcium hydroxide: a comparison of techniques, revisited. J Endod 2004; 30(4):225-7.

26. Peters CI, Koka RS, Highsmith S, Peters OA. Calcium hydroxide dressings using different preparation and application modes: density and dissolution by simulated tissue pressure. Int Endod J 2005; 38(12):889-95.
27. Rahde NM, Figueiredo JA, Oliveira EP. Influence of calcium hydroxide points on the quality of intracanal dressing filling. J Appl Oral Sci. 2006; 14:219-23.

28. Simcock RM, Hicks ML. Delivery of calcium hydroxide: comparison of four filling techniques. J Endod 2006; 32(7):680-2.

29. Vier-Pelisser FV, Meng A, Benedete Neto LC, Só MVR. Influence of instrumentation technique and apical preparation diameter on calcium hydroxide filling in simulated curved canals. Indian J Dent Res 2012; 23(6):784-8.

30. Só MVR, Cemin A, Pereira EP, Irala LED. Assessing the quality of root canal filling employing four different application methods of calcium hydroxide. Braz Endod J 1998; 3:49-54.

31. Peters OA. Current challenges and concepts in the preparation of root canal systems: a review. J Endod 2004; 30(8):559-67.

32. Baugh D, Wallace J. The role of apical instrumentation in root canal treatment: a review of the literature. J Endod 2005; 31(5):333-40.

33. Rollison S, Barnett F, Stevens RH. Efficacy of bacterial removal from instrumented root canals in vitro related to instrumentation technique and size. Oral Surg Oral Med Oral Pathol Oral Radiol Endod 2002; 94(3):366-71.

34. Lopez FU, Fachin EV, Camargo Fontanella VR, Barletta FB, So MV, Grecca FS. Apical transportation: a comparative evaluation of three root canal instrumentation techniques with three different apical diameters. J Endod 2008; 34(12):1545-8.

35. Bartha T, Kalwitzki M, Lost C, Weiger R. Extended apical enlargement with hand files versus rotary NiTi files. Part II. Oral Surg Oral Med Oral Pathol Oral Radiol Endod. 2006; 102(5):692-7.

\section{Corresponding author:}

Renata Dornelles Morgental

School of Dentistry - PUCRS

Av. Ipiranga 6681

90619-900 Porto Alegre/RS, Brazil

Phone: +55 (51) 33203538

E-mail: remorgental@hotmail.com

Recebido: 02/10/2013. Aceito: 02/02/2014. 